\title{
Principal Components-based Investigative Study of Counter Measures to Financial Crimes
}

\author{
Gabriel Babatunde Iwasokun ${ }^{1}$, Raphael Olufemi Akinyede ${ }^{1} \&$ Oniyide Alabi Bello ${ }^{2}$ \\ ${ }^{1}$ Department of Computer Science, Federal University of Technology, Akure, Nigeria \\ ${ }^{2}$ Department of Computer Science, Afe Babalola University, Ado-Ekiti, Nigeria \\ Correcpondence: Gabriel Babatunde Iwasokun, Department of Computer Science, Federal University of Technology, \\ Akure, Nigeria
}

Received: December 11, 2017

Accepted: February 8, 2018

Online Published: March 20, 2018

doi:10.5430/ijfr.v9n2p150

URL: https://doi.org/10.5430/ijfr.v9n2p150

\begin{abstract}
Financial crime is presently a very serious threat to the global, regional and national economies as it manifests itself in several financial institutions and government agencies. One of the reasons for the thriving status of the menace has been lack of globally acknowledged counter measures. Based on this, twenty eight indices that were considered to be related to financial crimes were formulated in this research. A questionnaire was formulated based on the indices and administered on selected financial related agencies and parastatals in States across Nigeria to obtain relevant data which were subjected to Principal Component Analyses (PCA) using SPSS. The analyses showed that effective citizens' control and monitoring, economic and social stability, moral suasion and political security and goodwill are the much desired counter-measures to financial crime. The percentage of relevance of these measures was $64.17 \%$, indicating that the indices of some extraneous counter-measures were not given consideration in the research. Such measures include but not limited to good governance, financial security and moral training. A coefficient score matrix was also generated for the estimation and ranking of the contribution of every respondent to the extracted counter-measures.
\end{abstract}

Keywords: Principal Component Analysis (PCA), Multivariate Statistical Technique (MST), orthogonal transformation, economic and financial crime

\section{Introduction}

Financial crime is a non-violent crime committed for monetary, property or any other unlawful or illicit gain from individuals, corporations, government bodies and financial institution (IMF, 2001). Financial crime is also an act or a practice, which is detrimental to the interest, development or well-being of the financial sector of a country (Ladan, 2005). Important characteristics of financial crime include deceit, concealment or violation of trust which are not dependent on the application of threat, physical force or violence. It may be committed individually or collectively in an organized manner thereby violating existing legislation on the economic activities of government and its administration. Economic and financial related crimes remain the bane of Nigerian developmental efforts as her economy is being subverted and the standard of lives going on a fallen trend. The nation is notably known for money laundering, inflated contracts, scam mails, illegal oil bunkering and mining as well as fuel diversion on the roads and seaways. Nigeria is also not spared from narcotic drug trafficking, embezzlements, bribery, looting, illegal arms deal, smuggling, human trafficking and child labor, tax evasion as well as foreign exchange malpractices such as counterfeiting of currency, theft of intellectual property and piracy and open market abuse (Adegbie and Fakile, 2012; Ibrahim et al., 2015; EFCC, 2004; Agus et al., 2010; Gottschalk, 2010; Spencher and Pickett, 2002). The steps being taken to address the problem of financial crimes in Nigeria include the expression of strong political will at the highest level as appropriate legislation was being enacted to criminalize all corrupt conducts including unjust enrichment, provision for interim restraints, forfeiture of tainted property as well as institution of special or designated courts/judges to expeditiously try financial crime cases. There is also the use of technology and establishment of various agencies and commissions such as the Economic and Financial Crimes Commission (EFCC) and Independent Corrupt Practices Commission (ICPC) (Adegbie and Fakile, 2012; Akomaye, 2007; Deloitte, 2014). While technological-based tools give organizations a more holistic view of data, highlight potential areas of risk and allow more focused and targeted combat-efforts, the goals of the agencies and commissions are to prevent and detect 
financial crimes through setting up of relevant laws and litigation measures. Several of the existing technology-based tools for combating financial crime rely on the concept of big data, machine and text mining as well as forensic accounting. All these steps and strategies could not work effectively because of various challenges like politicization and blackmail, constitutional immunity as enshrined in the Nigerian constitution, public apathy and doubtful attitudes towards anti-corruption work, and slow justice (Adegbie et al., 2012). Section 2 of this paper presents the PCA model for the investigative study of financial crimes' counter measures. Sections 3 and 4 present the data survey and the results and discussion respectively. The conclusion drawn formed the focus of Section 5.

\section{Principal Component Analysis (PCA) Model}

A PCA-based model for the investigative study of the counter measures to financial crime based on some formulated indices is used. PCA is a Multivariate Statistical Technique (MST) that is useful in the dimensionality reduction of a large number of interrelated variables while retaining as much vital information as possible (Pearson, 1901; Hotelling, 1933; Jolliffe, 2002; Srinivasulu et al., 2010). The indices formed the vital components of the research instrument (Questionnaire) and are related to one another for the $\mathrm{i}^{\text {th }}$ respondents as follows (Shehu et al.,2012):

$$
Y_{j}=\sum_{k=1}^{p} \alpha_{j k} X_{k} ; j=1,2, \ldots, p
$$

$Y_{j}$ represents the $j^{\text {th }}$ respondent, $\alpha_{j k}$ represents the assessment of the $j^{\text {th }}$ indices by $k^{\text {th }}$ respondent, $X_{k}$ represents the $\mathrm{k}^{\text {th }}$ index and $\mathrm{p}$ is the number of indices. PCA is used to generate some clusters of performance indices, where each cluster represents a component with associated percentage contribution. Descriptive statistics, communality, correlation matrix, Bartlett and Kaiser-Mayer Olkin (KMO) tests, component extraction and eigenvalues formed the focus of the analyses. The descriptive statistics provide the basic features of the data and include the mean, standard deviation, variance and covariance. The communality of the squared factor loadings for component $i$ is its proportion of variation that is explained by the extracted factors and is computed as follows:

$$
c_{i}=\alpha_{i 1}^{2}+\alpha_{i 2}^{2}+\cdots+\alpha_{i p}^{2}=\sum_{i=1}^{p} \alpha_{i p}^{2}
$$

$\mathrm{p}$ is the number of variables, $\alpha_{\mathrm{ip}}$ is the value in $\mathrm{Y}$ for row $i$, column $p$. The communalities narrate how well the model works for each variable while the correlation matrix describes the correlations between all pairs of dataset. A positive value in the correlation shows a positive relationship while a negative value dictates a negative relationship. The Bartlett's test of sphericity and the Kaiser-Mayer Olkin test give the adequacy measure of the sample from the population. While Bartlett's test examines the null hypothesis that the variables in the population correlation matrix are uncorrelated, KMO test indicates the level of uniqueness and correlations between used and unused variables (Rencher, 2002).

Given a p-dimensional random vector $X=\left[\begin{array}{llllll}X_{1}, & X_{2}, & \ldots . & X_{P}\end{array}\right]$ with correlation matrix $\rho$ and eigenvalues $\lambda_{1} \geq \lambda_{2} \geq \ldots, \lambda_{p} \geq$, the $j$ principal components $(j \in p)$ of $X$ are $j$ random variables $\left(Y_{1}, Y_{2}, \ldots, Y_{k}\right)$ defined for $\mathrm{k}=1,2, \ldots, \mathrm{p}$ as follows (Martin et al, 2013; Bello et al.,2014):

$$
\mathrm{Y}_{\mathrm{j}}=\sum_{1}^{\mathrm{p}} \alpha_{\mathrm{jk}} \mathrm{X}_{\mathrm{k}}
$$

The first principal component is the linear combination with the maximum variance. Although, there is likelihood of p such linear combinations, the first few is always taken to explain the variance in the original data. The existing options for the determination of the number of principal components to retain are the Kaiser option, scree test and the proportion of total variance (Kaiser, 1960; Cattell, 1966). Kaiser criterion states that any principal component with the eigenvalue greater than a calculated threshold must be part of the analysis. Scree test uses the plot of the magnitude of observed individual eigenvalue and the component to determine the appropriate number of components. The components that appear before the break are assumed to be meaningful and retained. The proportion of total variance is a measure of how well the first q principals explain the original variables. The initial extractions are subjected to orthogonal rotation using varimax, equimax, quartimax and promax and the best result is taken for much easier interpretation. Orthogonal transformation is used to obtain meaningful representation of variables and component mapping along the principal axis. Rotation by varimax is based on the assumption that the interpretability of a factor can be measured by the variance of the squares of its factor loadings. Quartimax rotation involves the minimization of the number of factors needed to explain each variable while equamax rotation is a compromise that attempts to simplify both components and variables. Promax is an oblique rotation that allows factors to be correlated and because it is often more easily calculated than any direct oblimin rotation, it is more useful for large datasets. A symmetric, non-singular matrix $\rho$ can be reduced to a diagonal matrix by multiplying with eigenvectors as follows:

$$
D=U^{\prime} \rho \mathrm{U}
$$


$\mathrm{D}$ is the diagonal matrix of eigenvalues and $\mathrm{U}$ is the eigenvector. The variance in the correlation matrix is "repackaged" into $p$ eigenvalues. Each eigenvalue represents the amount of variance that is attributed to each component.

\section{Data Survey}

The Questionnaire shown in Appendix 1 was designed using the formulated indices for the investigative study of the counter measures to financial crimes. Each of these indices was offered loosed linguistic description and range of values as shown in Table 1.

Table 1. Matrix of weight attached to linguistic value

\begin{tabular}{llllll}
\hline Linguistic Representation & Excellent & Very Good & Good & Average & Poor \\
\hline Range of Values & $4.01-5.0$ & $3.01-4.0$ & $2.01-3.0$ & $1.01-2.0$ & $0.0-1.0$ \\
\hline
\end{tabular}

The first part of the Questionnaire provided vital information about each respondent while the second part presented five columns for the respondent to rank each of the twenty eight indices based on the scale presented in Table 1 . The Questionnaire was administered to respondents from several financial institutions, government agencies and individuals in Thirty States across the six geo-political zones and the Federal Capital Territory (FCT) in Nigeria and the summary of the survey is presented in Table 2.

Table 2. Summary of the survey

\begin{tabular}{|c|c|c|c|c|c|}
\hline Serial Number & State & $\begin{array}{l}\text { Local } \\
\text { Number of Government Surveyed }\end{array}$ & $\begin{array}{l}\text { Total } \\
\text { Administered }\end{array}$ & $\begin{array}{l}\text { Total } \\
\text { Returned }\end{array}$ & $\begin{array}{l}\text { Total } \\
\text { not Returned }\end{array}$ \\
\hline 1 & Abia & 5 & 300 & 263 & 37 \\
\hline 2 & Adamawa & 6 & 425 & 415 & 10 \\
\hline 3 & Akwa-Ibom & 8 & 524 & 522 & 2 \\
\hline 4 & Anambra & 5 & 275 & 254 & 21 \\
\hline 5 & Bauchi & 7 & 589 & 487 & 102 \\
\hline 6 & Benue & 7 & 652 & 623 & 29 \\
\hline 7 & Delta & 10 & 524 & 451 & 73 \\
\hline 8 & Cross River & 11 & 687 & 671 & 16 \\
\hline 9 & Ebonyi & 6 & 165 & 128 & 37 \\
\hline 10 & Edo & 8 & 785 & 687 & 98 \\
\hline 11 & Ekiti & 7 & 570 & 457 & 113 \\
\hline 12 & Enugu & 8 & 622 & 528 & 94 \\
\hline 13 & Imo & 7 & 522 & 420 & 102 \\
\hline 14 & Jigawa & 3 & 420 & 259 & 161 \\
\hline 15 & Kaduna & 3 & 186 & 181 & 5 \\
\hline 16 & Kano & 11 & 894 & 856 & 38 \\
\hline 17 & Kebbi & 3 & 202 & 202 & 0 \\
\hline 18 & Kogi & 6 & 414 & 401 & 13 \\
\hline 19 & Kwara & 4 & 551 & 510 & 41 \\
\hline 20 & Lagos & 20 & 1026 & 896 & 130 \\
\hline 21 & Nasarawa & 6 & 239 & 239 & 0 \\
\hline 22 & Ogun & 7 & 658 & 452 & 206 \\
\hline 23 & Niger & 8 & 659 & 659 & 0 \\
\hline 24 & Ondo & 18 & 1524 & 1325 & 199 \\
\hline 25 & Osun & 8 & 354 & 258 & 96 \\
\hline 26 & Oyo & 12 & 742 & 468 & 274 \\
\hline 27 & Plateau & 6 & 231 & 197 & 34 \\
\hline 28 & Rivers & 6 & 402 & 401 & 1 \\
\hline 29 & Sokoto & 3 & 189 & 175 & 14 \\
\hline 30 & Taraba & 5 & 580 & 574 & 6 \\
\hline 31 & FCT & 3 & 627 & 587 & 40 \\
\hline Total & & 158 & 16538 & 14546 & 1789 \\
\hline
\end{tabular}


A total of Sixteen Thousand Five Hundred and Thirty Eight (16538) copies of the Questionnaire were administered through direct and online contacts. In the direct contact, the researchers visited the surveyed states or engaged the services of third parties while indirect contact involved hosting the Questionnaire on Google forms for online assessment. From the two contact methods, a total of Fourteen Thousand Five Hundred and Forty Six (14546) respondents returned duly completed Questionnaires. Where necessary, the responses were verified and validated through follow-up meetings and personal interviews.

\section{Results and Interpretation}

The data from the 14546 responses were subjected to PCA using SPSS. The analysis of the respondents' age, computer literacy level, knowledge of financial crime, distribution of occurrences and frequency of financial crimes experienced are presented in Tables 3, 4, 5, 6 and 7 respectively.

Table 3. Respondents' age distribution

\begin{tabular}{llll}
\hline Age & Frequency & Percent & Cumulative Percent \\
\hline $11-18$ & 640 & 4.4 & 4.4 \\
\hline $19-44$ & 13336 & 91.7 & 96.1 \\
\hline$>44$ & 570 & 3.9 & 100.0 \\
\hline Total & 14546 & 100.0 & \\
\hline
\end{tabular}

Table 4. Computer literacy level of respondents

\begin{tabular}{llll}
\hline Values & Frequency & Percent & \% Cumulative \\
\hline Poor & 173 & 1.1 & 1.1 \\
\hline Average & 1954 & 13.4 & 14.6 \\
\hline Good & 3848 & 26.5 & 41.0 \\
\hline Very Good & 4713 & 32.4 & 73.4 \\
\hline Excellent & 3863 & 26.6 & 100.0 \\
\hline Total & 14546 & 100.0 & \\
\hline
\end{tabular}

Table 5. Respondents' knowledge of financial crime

\begin{tabular}{llll}
\hline Values & Frequency & Percent & \% Cumulative \\
\hline Poor & 988 & 6.8 & 6.8 \\
\hline Average & 3102 & 21.3 & 28.1 \\
\hline Good & 4803 & 33.0 & 61.5 \\
\hline Very Good & 3863 & 26.3 & 87.7 \\
\hline Excellent & 1790 & 12.3 & 100.0 \\
\hline Total & 14546 & 100.0 & \\
\hline
\end{tabular}

Table 6. Distribution of range of occurrences

\begin{tabular}{lllll}
\hline Range & Frequency & Percent & Valid Percent Cumulative Percent \\
\hline 0 & 11655 & 80.1 & & \\
\hline $1-5$ & 1372 & 9.4 & 47.4 & 47.4 \\
\hline $6-10$ & 447 & 3.1 & 15.4 & 62.8 \\
\hline $11-15$ & 164 & 1.1 & 5.7 & 68.5 \\
\hline $16-20$ & 357 & 2.5 & 12.4 & 80.9 \\
\hline$>20$ & 551 & 3.3 & 19.1 & 100.0 \\
\hline Total & 14546 & 100.0 & & \\
\hline
\end{tabular}


Table 7. Distribution of financial crime victims

\begin{tabular}{lll}
\hline Classes of Financial Crime & Number of Victims & $\%$ \\
\hline Advance fee fraud & 1218 & 12.72 \\
\hline Forgery (Fake Cheque) & 863 & 9.02 \\
\hline Money Theft Through ATM & 879 & 9.18 \\
\hline Kickbacks and Extortion & 755 & 7.89 \\
\hline Embezzlement & 801 & 8.37 \\
\hline Corruption and Bribery & 1048 & 10.95 \\
\hline Fraud & 895 & 9.34 \\
\hline Money Laundering & 554 & 5.8 \\
\hline Identity theft & 478 & 4.99 \\
\hline Counterfeit Money & 724 & 7.57 \\
\hline Financial Grooming & 662 & 6.92 \\
\hline Insider Trading & 385 & 4.03 \\
\hline Phishing & 307 & 3.22 \\
\hline Total & 9568 & 100 \\
\hline
\end{tabular}

Table 8 presents the means and standard deviation of the rating of the indices by the respondents. The mean and standard deviation of the rating on 'Political Will' are $3.40(68.0 \%)$ and 1.299 respectively while the mean and standard deviation of the rating on 'Industry Contribution' are $3.25(65.0 \%)$ and 1.170 respectively. The mean values reveal that on the average, the respondents gave a 'very good' rating of 'Political Will' and 'Industry Contribution' in combating financial crimes. Similarly, the standard deviations represent the statistical measure of dispersion from the mean for the two variables.

Table 8. Descriptive statistics of variables

\begin{tabular}{llll}
\hline Variables & N & Mean & Std. Deviation \\
\hline Political will & 13566 & 3.40 & 1.299 \\
Industry Contribution & 13535 & 3.25 & 1.170 \\
Funding of Research on Financial Security & 13535 & 3.19 & 1.235 \\
Societal Campaign & 13490 & 3.25 & 1.177 \\
Employment generation & 13597 & 3.20 & 1.381 \\
Economic and Political stability & 13520 & 3.25 & 1.315 \\
Moral upbringing & 13551 & 3.31 & 1.232 \\
Social equality and Fairness & 13643 & 3.16 & 1.264 \\
Pro-Active (Preventive) Measures & 13459 & 3.24 & 1.244 \\
Re-Active (Curative) Measures & 13535 & 3.14 & 1.187 \\
National orientation & 13581 & 3.21 & 1.204 \\
Religious campaign & 13459 & 3.20 & 1.211 \\
Public/Private Agency Collaboration & 13367 & 3.15 & 1.188 \\
Ruggedness of Financial System's Design & 13382 & 3.11 & 1.196 \\
Physical Security at Financial Institution & 13367 & 3.21 & 1.206 \\
Implementation of Appropriate Legislative Framework & 13382 & 3.18 & 1.162 \\
Implementation of Effective Investigative Framework & 13444 & 3.23 & 1.249 \\
Reward for Integrity, excellence and honesty & 13367 & 3.20 & 1.275 \\
Scalability of Hardware at Financial Installations & 13474 & 3.22 & 1.206 \\
Effectiveness of Financial Criminal Tracking Software & 13505 & 3.20 & 1.241 \\
Availability of Forensic Experts (Forensic Accounting) & 13398 & 3.19 & 1.263 \\
Execution of Regular Auditing in Financial Institutions & 13474 & 3.24 & 1.190 \\
Regular Staff Training on Financial Crime & 13306 & 3.23 & 1.187 \\
Internal Control System, Policies, Laws and Operations & 13444 & 3.21 & 1.204 \\
Adherence to Due Process & 13398 & 3.18 & 1.222 \\
Data Analytics and Visualization & 13382 & 3.22 & 1.203 \\
Effective Predictive Modelling and Strong Warning System & 13398 & 3.22 & 1.236 \\
Effective Financial Data Management & 13459 & 3.24 & 1.257 \\
\hline
\end{tabular}


The extracted communalities presented in Table 9 shows 0.801 for 'Political will'. This implies that $80.1 \%$ of the variance for 'Political will' can be explained by the extracted factors while the remaining $19.9 \%$ is attributed to some extraneous factors. Similarly, the extracted communality of 0.795 for 'Industry Contribution' implies that $79.5 \%$ and $20.5 \%$ of its variance are attributed to the extracted and extraneous factors respectively.

Table 9. Communalities of variables

\begin{tabular}{lll}
\hline Variables & Initial & Extraction \\
\hline Political will & 1.000 & 0.801 \\
Industry Contribution & 1.000 & 0.795 \\
Funding of Research on Financial Security & 1.000 & 0.738 \\
Societal Campaign & 1.000 & 0.700 \\
Employment generation & 1.000 & 0.785 \\
Economic Stability and Political stability & 1.000 & 0.768 \\
Moral upbringing & 1.000 & 0.677 \\
Social equality and Fairness & 1.000 & 0.674 \\
Pro-Active (Preventive) Measures & 1.000 & 0.769 \\
Re-Active (Curative) Measures & 1.000 & 0.772 \\
National orientation & 1.000 & 0.689 \\
Religious campaign & 1.000 & 0.663 \\
Public/Private Agency Collaboration & 1.000 & 0.699 \\
Ruggedness of Financial System's Design & 1.000 & 0.662 \\
Physical Security at Financial Institution & 1.000 & 0.729 \\
Implementation of Appropriate Legislative Framework & 1.000 & 0.696 \\
Implementation of Effective Investigative Framework & 1.000 & 0.711 \\
Reward for Integrity, excellence and honesty & 1.000 & 0.681 \\
Scalability of Hardware at Financial Installations & 1.000 & 0.656 \\
Effectiveness of Financial Transactions Tracking Software & 1.000 & 0.676 \\
Availability of Forensic Experts (Forensic Accounting) & 1.000 & 0.731 \\
Execution of Regular Auditing in Financial Institutions & 1.000 & 0.754 \\
Regular Staff Training on Financial Crime & 1.000 & 0.761 \\
Internal Control System, Policies, Laws and Operations & 1.000 & 0.700 \\
Adherence to Due Process & 1.000 & 0.679 \\
Data Analytics and Visualization & 1.000 & 0.767 \\
Effective Predictive Modelling and Strong Warning System & 1.000 & 0.757 \\
Effective Financial Data Management & 1.000 & 0.700 \\
\hline
\end{tabular}

The analysis of correlation matrix presented in Appendix 2 shows a highest correlation of 0.716 exists between 'Economic and Political Stability' and 'Employment Generation'. The next highest correlation of 0.692 exists between 'Effectiveness of Financial Criminal Tracking Software' and 'Availability of Forensic Experts (Forensic Accounting)'. The implication of the former is that 'Economic and Political Stability' is most likely to share the same factor with 'Employment Generation'. Similarly, in the later, 'Effectiveness of Financial Criminal Tracking Software' will likely share same factor with 'Availability of Forensic Experts (Forensic Accounting)'. The Least correlation of 0.319 exists between 'Religious Campaign' and 'Availability of Forensic Experts (Forensic Accounting)'. This means that 'Religious campaign' and 'Availability of Forensic Experts (Forensic Accounting)' are not likely to share the same factor. The Barlett test of sphericity produced a $\chi^{2}$ of 14377.321 with significance level of 0.000 which indicates that the sample population is adequate. In addition, Kaiser-Mayer Olkin (KMO) test produced a measure of 0.966 to further confirm the adequacy of the sample population. The application of Kaiser Criterion and Interpretability test on the initial components led to the initial extractions presented in Table 10. 
Table 10. Extracted components matrix

\begin{tabular}{|c|c|c|c|c|}
\hline \multirow[b]{2}{*}{ Variables } & \multicolumn{4}{|c|}{ Component } \\
\hline & 1 & 2 & 3 & 4 \\
\hline Reward for Integrity, excellence and honesty & 0.758 & & & \\
\hline Data Analytics and Visualization & 0.757 & & & \\
\hline Pro-Active (Preventive) Measures & 0.749 & & & \\
\hline Availability of Forensic Experts (Forensic Accounting) & 0.747 & & & \\
\hline Employment generation & 0.741 & & & \\
\hline Funding of Research on Financial Security & 0.735 & 0.332 & & \\
\hline Regular Staff Training on Financial Crime & 0.734 & & & \\
\hline Adherence to Due Process & 0.734 & & & \\
\hline Effectiveness of Financial Transactions Tracking Software & 0.732 & & & \\
\hline Social equality and Fairness & 0.730 & & & \\
\hline Economic and Political stability & 0.727 & & -0.302 & \\
\hline Effective Predictive Modelling and Strong Warning System & 0.726 & & & \\
\hline Moral upbringing & 0.721 & & & \\
\hline Scalability of Hardware at Financial Installations & 0.715 & & & \\
\hline Effective Financial Data Management & 0.714 & & & \\
\hline Implementation of Effective Investigative Framework & 0.711 & & & \\
\hline Internal Control System, Policies, Laws and Operations & 0.708 & -0.349 & & \\
\hline Societal Campaign & 0.704 & & & \\
\hline National orientation & 0.701 & & & \\
\hline Implementation of Appropriate Legislative Framework & 0.700 & & & \\
\hline Execution of Regular Auditing in Financial Institutions & 0.694 & -0.333 & & \\
\hline Ruggedness of Financial System's Design & 0.681 & & 0.344 & \\
\hline Public/Private Agency Collaboration & 0.677 & & 0.451 & \\
\hline Re-Active (Curative) Measures & 0.668 & & & \\
\hline Industry Contribution & 0.663 & 0.348 & & 0.375 \\
\hline Physical Security at Financial Institution & 0.654 & & 0.345 & \\
\hline Political will & 0.610 & 0.356 & & 0.439 \\
\hline Religious campaign & 0.605 & & 0.468 & \\
\hline
\end{tabular}

The extracted components were rotated using or thogonal transformation techniques. Rotation by Varimax produced the best result and it is presented in Table 11 showing four factors with their corresponding loadings.

Table 11. Rotated extracted component matrix

\begin{tabular}{|c|c|c|c|c|}
\hline \multirow[b]{2}{*}{ Variables } & \multicolumn{4}{|c|}{ Component } \\
\hline & 1 & 2 & 3 & 4 \\
\hline Availability of Forensic Experts (Forensic Accounting) & 0.709 & & & \\
\hline Execution of Regular Auditing in Financial Institutions & 0.703 & & & \\
\hline Internal Control System, Policies, Laws and Operations & 0.702 & & & \\
\hline Effectiveness of Financial Transactions Tracking Software & 0.690 & & & \\
\hline Regular Staff Training on Financial Crime & 0.679 & & & \\
\hline Adherence to Due Process & 0.678 & & & \\
\hline Data Analytics and Visualization & 0.641 & & & \\
\hline Scalability of Hardware at Financial Installations & 0.620 & & & \\
\hline Reward for Integrity, excellence and honesty & 0.590 & & & \\
\hline Effective Predictive Modelling and Strong warning System & 0.567 & & & \\
\hline Effective Financial Data Management & 0.536 & & & \\
\hline Implementation of Effective Investigative Framework & 0.515 & & & 0.441 \\
\hline
\end{tabular}


Implementation of Appropriate Legislative Framework

Economic and Political stability

Employment generation

Social equality and Fairness

Moral upbringing

Pro-Active (Preventive) Measures

Societal Campaign

Re-Active (Curative) Measures

Religious campaign

Public/Private Agency Collaboration

National orientation

Ruggedness of Financial System's Design

Physical Security at Financial Institution

Political will

Industry Contribution

Funding of Research on Financial Security
0.495

0.420

0.710

0.694

0.667

0.659

0.625

0.570

0.427

0.516

0.733

0.715

0.614

0.609

0.411

0.560
0.748

0.744

0.607

Table 11 reveals four clusters with each presenting a set of variables that align to form a counter measure to financial crime. Cluster 1 (Control and Monitoring) loads on Availability of Forensic Experts (Forensic Accounting), Execution of Regular Auditing in Financial Institutions, Internal Control System, Policies, Laws and Operations, Effectiveness of Financial Transactions Tracking Software, Regular Staff Training on Financial Crime and Adherence to Due Process. It also loads on Data Analytics and Visualization, Reward for Integrity, Excellence and Honesty, Effective Predictive Modeling and Strong Warning System, Effective Financial Data Management, Implementation of Effective Investigative Framework and Implementation of Appropriate Legislative Framework. Cluster 2 (Economic and Social stability) loads on Economic and Political stability, Employment Generation and Social Equality and Fairness. It also loads on Moral Upbringing, Pro-Active (Preventive) Measures, Re-Active (Curative) Measures and Societal Campaign. Cluster 3 (Moral Suasion and Partnership) loads on Religious Campaign, Public/Private Agency Collaboration, National Orientation, Re-Active (Curative) Measures and Ruggedness of Financial System Design. Cluster 4 (Political stability and goodwill) loads on Political Will, Industry Contribution and Funding of Research on Financial Security. The eigenvalues of the extracted factors is presented in Figure 1.

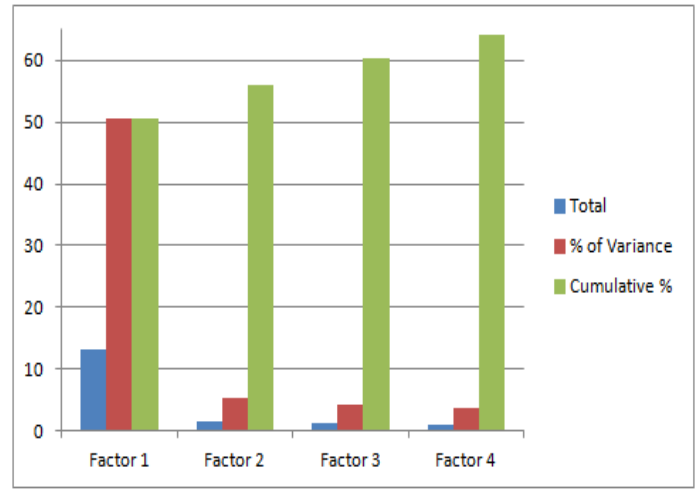

Figure 1. Eigen values of factors

The four clusters contributed $64.17 \%$ of the extracted counter measures with Cluster 1 emerging as the most significant with $50.59 \%$ contributions. This result established that very enduring control and monitoring strategies are much desired to effectively combat financial crime. This corroborated the views of the authors in (Mohammed, 2012; Sofia de Oliveira et al., 2016) that sanctions, stringent financial control and monitoring policies as well as compliances with regulations must be held in high esteem at every strata of the economy of a nation if all forms of financial crimes are to be curbed. Clusters 2, 3 and 4 showed the percentage contributions of $5.33 \%, 4.44 \%$ and $3.82 \%$ respectively. These results also established economic and social stability, moral suasion and partnership as well as political stability and goodwill on the part of leaders as essential requirements for government at all levels if 
financial crime is to be effectively checked. This view has been the opinion of the author in (Nakajima, 2007; Kasum, 2009; Nwosumba, 2016; Thomson, 2012; Sofia de Oliveira et al., 2016) who stated that increased peoples' awareness, public and private sectors partnership and continuous research and training are the panacea to the scourge of financial crime. The obtained coefficient matrix is shown in Table 12. The matrix is obtained by forming a linear equation of the weighted standard scores of each respondent on the variables. Given that the standard scores by the $\mathrm{b}^{\text {th }}$ respondent in the twenty-eight variables under consideration are $\mathrm{W}_{\mathrm{b}, 1}, \mathrm{~W}_{\mathbf{b}, 2}, \mathrm{~W}_{\mathbf{b}, 3} \ldots, \mathrm{W}_{\mathbf{b}, 28 \text {, }}$, then the view of each respondent on control and monitoring, economic and social stability, moral suasion and partnership and political stability and goodwill is denoted by $\mathrm{M}_{1} \mathrm{M}_{2}, \mathrm{M}_{3}$, and $\mathrm{M}_{4}$ respectively and modeled as follows:

$$
\begin{aligned}
& M_{1}=-0.109 W_{b, 1}-0.099 W_{b, 2}+\cdots+0.087 W_{b, 28} \\
& M_{2}=-0.130 W_{b, 1}-0.049 W_{b, 2}+\cdots+0.050 W_{b, 26} \\
& M_{3}=-0.005 W_{b, 1}-0.081 W_{b, 2}+\cdots+0.067 W_{b, 26} \\
& M_{4}=+0.468 W_{b, 1}-0.081 W_{b, 2}+\cdots-0.154 W_{b, 26}
\end{aligned}
$$

\begin{tabular}{|c|c|c|c|c|}
\hline \multirow[b]{2}{*}{ Variables } & \multicolumn{4}{|c|}{ Component } \\
\hline & 1 & 2 & 3 & 4 \\
\hline Political will & -.109 & -.130 & -.005 & .468 \\
\hline Industry Contribution & -.099 & -.049 & -.081 & .442 \\
\hline Funding of Research on Financial Security & -.112 & .058 & -.039 & .288 \\
\hline Societal Campaign & -.079 & .193 & -.108 & .132 \\
\hline Employment generation & -.047 & .303 & -.134 & -.027 \\
\hline Economic and Political stability & -.061 & .321 & -.139 & -.024 \\
\hline Moral upbringing & -.067 & .287 & -.030 & -.099 \\
\hline Social equality and Fairness & -.066 & .291 & -.021 & -.114 \\
\hline Pro-Active (Preventive) Measures & -.097 & .243 & .053 & -.083 \\
\hline Re-Active (Curative) Measures & -.128 & .185 & .183 & -.123 \\
\hline National orientation & -.105 & .032 & .267 & -.050 \\
\hline Religious campaign & -.155 & -.053 & .394 & -.023 \\
\hline Public/Private Agency Collaboration & -.063 & -.081 & .360 & -.084 \\
\hline Ruggedness of Financial System's Design & -.026 & -.103 & .271 & -.010 \\
\hline Physical Security at Financial Institution & .031 & -.253 & .238 & .125 \\
\hline Implementation of Appropriate Legislative Framework & .076 & -.167 & .043 & .173 \\
\hline Implementation of Effective Investigative Framework & .087 & -.079 & -.078 & .183 \\
\hline Reward for Integrity, excellence and honesty & .118 & -.014 & -.110 & .092 \\
\hline Scalability of Hardware at Financial Installations & .158 & -.125 & -.045 & .090 \\
\hline Effectiveness of Financial Criminal Tracking Software & .199 & -.042 & -.153 & .042 \\
\hline Availability of Forensic Experts (Forensic Accounting) & .207 & -.029 & -.157 & .020 \\
\hline Execution of Regular Auditing in Financial Institutions & .222 & -.106 & -.063 & -.022 \\
\hline Regular Staff Training on Financial Crime & .186 & -.036 & -.042 & -.073 \\
\hline Internal Control System, Policies, Laws and Operations & .210 & -.036 & -.016 & -.147 \\
\hline Adherence to Due Process & .185 & -.054 & -.005 & -.090 \\
\hline Data Analytics and Visualization & .146 & -.002 & .045 & -.149 \\
\hline Effective Predictive Modelling and Strong warning System & .105 & .015 & .071 & -.139 \\
\hline Effective Financial Data Management & .087 & .050 & .067 & -.154 \\
\hline
\end{tabular}

Table 12. Component score coefficient matrix

Based on Table 1, the standard scores by ten randomly selected respondents for each of the twenty-eight variables under consideration are presented in Table 13. Figure 2 shows the calculated percentage contributions of each of the ten sampled respondents to each of the four clusters. 
Table 13. Standard score of 10 respondents

\begin{tabular}{|c|c|c|c|c|c|c|c|c|c|c|c|c|}
\hline Respondents & 量 & $\overline{\bar{\Omega}}$ & $\begin{array}{l}\bar{T} \\
\bar{\Xi} \\
\bar{D}\end{array}$ & $\begin{array}{l}\tilde{\delta} \\
\tilde{8} \\
\tilde{\Xi}\end{array}$ & $\begin{array}{l}\bar{\pi} \\
\stackrel{5}{\circ} \\
g\end{array}$ & $\begin{array}{l}\overline{1} \\
0 \\
0 \\
\sigma \\
\sigma\end{array}$ & 艿 & $\begin{array}{l}\tilde{D} \\
0 \\
0 \\
0 \\
0\end{array}$ & 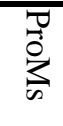 & $\begin{array}{l}\bar{\pi} \\
\stackrel{0}{\xi} \\
\stackrel{3}{*}\end{array}$ & $\begin{array}{l}Z \\
\text { Z } \\
0\end{array}$ & 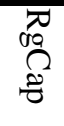 \\
\hline Res1 & 2 & 3 & 3 & 3 & 2 & 2 & 2 & 3 & 2 & 4 & 3 & 3 \\
\hline Res2 & 5 & 4 & 5 & 5 & 4 & 5 & 5 & 4 & 5 & 4 & 5 & 5 \\
\hline Res3 & 2 & 5 & 2 & 2 & 2 & 1 & 2 & 2 & 3 & 2 & 2 & 1 \\
\hline Res4 & 2 & 1 & 2 & 1 & 1 & 1 & 1 & 2 & 1 & 1 & 1 & 2 \\
\hline Res5 & 4 & 4 & 2 & 3 & 3 & 3 & 3 & 2 & 2 & 3 & 3 & 3 \\
\hline Res6 & 3 & 4 & 3 & 4 & 2 & 2 & 3 & 4 & 3 & 3 & 2 & 2 \\
\hline Res7 & 4 & 4 & 5 & 3 & 3 & 5 & 5 & 1 & 5 & 5 & 5 & 5 \\
\hline Res8 & 2 & 3 & 3 & 2 & 2 & 2 & 2 & 1 & 2 & 3 & 1 & 2 \\
\hline Res9 & 3 & 3 & 2 & 3 & 3 & 3 & 1 & 2 & 2 & 3 & 3 & 3 \\
\hline Res 10 & 3 & 3 & 2 & 3 & 2 & 2 & 3 & 2 & 3 & 3 & 3 & 4 \\
\hline
\end{tabular}

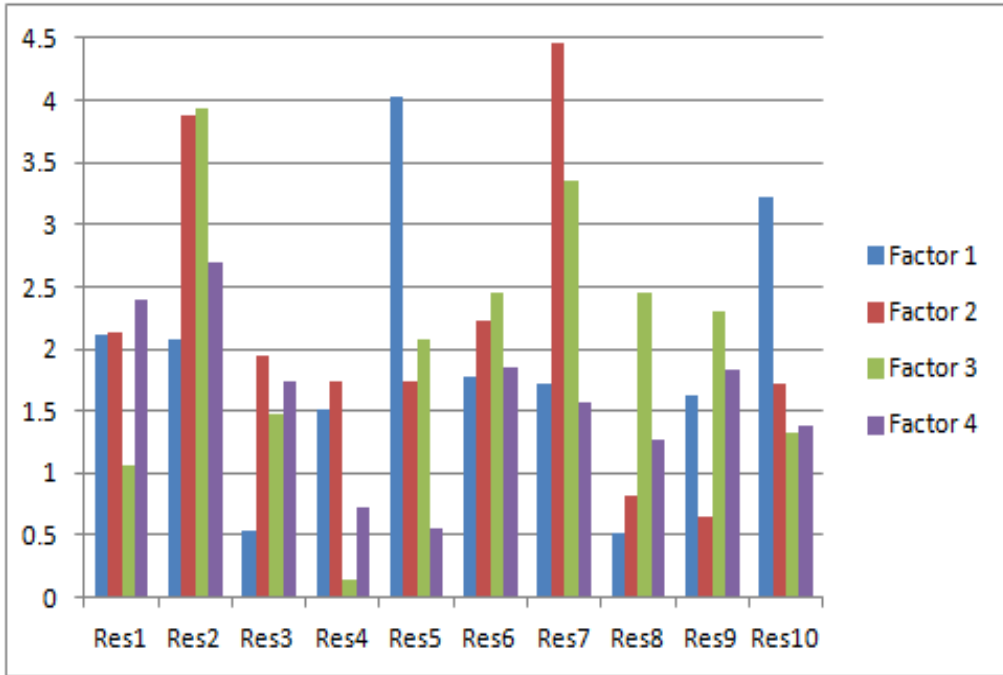

Figure 2. Aggregate factor scores with percentage contributions for a subset of respondents

\section{Conclusion}

Nigerians have continued to suffer different degree of losses arising from financial crime. It has also come to the knowledge of government, groups and individuals that something urgent must be done to curb the activities of financial criminals. In view of this, a PCA-based investigative study of the counter-measures to financial crimes was carried out. The study led to the generation of a component matrix which was subjected to orthogonal transformation with a view to discover reasonable factorization of the indices. The transformation established four counter measures with each of them loading on some related indices (variables). A counter-measure score coefficient matrix was also generated to serve as basis for determining the contribution of each respondent. The obtained eigenvalue of each extracted counter-measure formed the basis of the evaluation of its percentage contribution. The aggregate percentage contribution of the four extracted counter-measures was less than 100 signalling that the related indices of some extraneous (latent) counter-measures were left out in the research instrument. The results of the study placed high premium on control and monitoring, economic and social stability, moral suasion and partnership, political stability and goodwill as veritable tools for combating financial crime. This corroborated the views of the authors in (Mohammed, 2012; Sofia de Oliveira et al., 2016) that sanctions, stringent financial control and monitoring policies as well as compliances with regulations must be held in high esteem at every strata of the economy of a nation if all forms of financial crimes are to be curbed. These results also agreed with the opinion of the author in (Nakajima, 2007; Kasum, 2009; Nwosumba, 2016; Thomson, 2012; Sofia de Oliveira et al., 2016) who stated that 
increased peoples' awareness, public and private sectors partnership and continuous research and training are the panacea to the scourge of financial crime.

In view of the very high emphasis on economic and social stability, it can be deduced that illiteracy, high population density, unemployment and poverty contributed immensely to financial crime. It is therefore required that government at all levels should double its efforts to reduce the levels of illiteracy, unemployment and poverty through better funding education, actualization of small, medium and large scale industries and massive investment in Agriculture. It is also required that government employs more security personnel for better monitoring, control, prevention and management of financial crime.

\section{References}

Adegbie, F., \& Fakile, A. (2012). Economic and Financial Crime in Nigeria: Forensic Accounting. British Journal of Arts and Scocial Sciences, 6.

Agus, S., Nair, S., Yuan, M., Zhang, A., Kern, D., \& Cala-Diaz, F. (2010). Statistical Methods For Fighting Financial Crimes. TECHNOMETRICS, 5-19.

Akomaye, E. (2007). Nigerian Experience in Combating Corruption. Paper Presented at Ad-hoc Experts Group Meeting on Deeping Judiciary's Effectiveness in Combating Corruption, Addis Ababa, Ethiopia

Alexei Monsarrat. (2012). Encouraging Public-Private Partnerships to Fight Financial Crime. Retrieved from http://www.atlanticcouncil.org/publications/issue-briefs/encouraging-publicprivate-partnerships-to-fight-financi al-crime

Bello, Y., Batsari, Y. U., \& Charanchi, A. S. (2014). Principal Component Analysis of Crime Victimizations in Katsina Senatorial Zone. International Journal of Science and Technology.

Cattell, R. (1966). The scree test for the number of factors. Multivariate Behavioral Research, 1, 245-276.

Deloitte. (2014). Risk Angles: Five questions on financial crime. Deloitte Touche Tohmatsu Limited.

Economic and Financial Crimes Commission (EFCC). (2004). Economic and Financial Crimes Commission act (ESTABLISHMENl).

Gottschalk, P. (2010). Categories of Financial Crime. Journal of Financial Crime.

Hotelling, H. (1933). Analysis of a Complex of Statistical Variables Into Principal Components. Journal of Educational Psychology, 24, 417-441, 498-520.

Ibrahim, J., Adeyemi, M., \& Odunayo, K. (2015). Implication of Financial Crimes and Corruption on Manufacturing Firms in Osun State, Nigeria. European Journal of Business and Management.

International Monetary Fund (IMF). (2001). Financial System Abuse, Financial Crime and Money LaunderingBackground Paper.

Jolliffe, I. T. (2002). Principal Component Analysis. Springer.

Kaiser, H. F. (1960). The Application of Electronic Computers to Factor Analysis. Education and Psychologic Measurement, 141-151.

Kasum, A. S. (2009). The Relevance of Forensic Accounting to Financial Crimes in Private and Public Sectors of Third World Economies: A Study from Nigeria. SRN Electronic Journal.

Ladan, M. (2005). Crime Prevention and Control and Human Rights in Nigeria.

Martin, A. O., Prince, K. K., Dadzie, J., \& Ben, A. D. (2013). Application of Principal Components Analysis On Venture Capital Investment Decision Process in Ghana.

Mohammed, F. (2012). Financial Crime and its Implications on Nigeria's social Image. International Journal of Economic Development Research and Investment, 3.

Nakajima, C. (2007). Crime Editorial: Issues in Fighting Financial Crimes. Journal compilation () Institute of Economic Affairs.

Nwosumba, V. C. (2016). An Appraisal of the Economic and Financial Crimes Commission in the Light of the Disaster of the Nigerian Anti-Corruption Politics 2002-2015. IOSR Journal of Humanities and Social Science, 21(2), 43-55. 
Pearson, K. (1901). On Lines and Planes of Closest Fit to Systems of Points. Philosophical Magazine, Series 6, 2(11), 559-572.

Rencher, A. C. (2002). Methods of Multivariate Analysis. John Wiley \& Sons, Inc. .

Shehu, G. U., Dikko, H., \& Yusuf, B. (2012). Analysis of Crime Data Using Principal Component Analysis: A Case Study of Katsina State.

Sofia de Oliveira, I., Keatinge, T., \& Stickings, A. (2016). Building Trust and Taking Risks in the Global Effort to Tackle Financial Crime. RUSI Occasional Paper.

Spencer, P., \& Pickett, J. (2002). Financial Crime, Investigation and Control. John Wiley and Sons, Inc.

Srinivasulu, A. D., Subba, D. R., \& Saikrishna, V. (2010.). A Comparative Study of Face Recognition with Principal Component Analysis and Cross-Correlation Technique. International Journal of Computer Applications, 10.

\section{Appendix 1: Questionnaire on Analysis of Counter Measures to Financial Crime in the Scenery of Nigeria}

The purpose of this Questionnaire is to conduct investigative study on counter measures to financial crimes in Nigerian with a view to developing a pro-active solution. Confidentiality of personal information is guaranteed. We would therefore appreciate your sincere contributions to the research by giving a very accurate and honest response to this Questionnaire.

Section A: Profile of Respondents

1. AGE (Please Tick as appropriate)

$$
\overline{5-10}
$$

$\overline{11-18}$

$\overline{19-44}$

2. SEX (Please Tick as appropriate)

Male $\quad$ Female

3. HIGHEST ACADEMIC QUALIFICATION (Please Tick as appropriate)

$$
\text { Primary Schl. Cert. }
$$

O. Level

A. Level

B. Sc./B. Tech.

M. Sc./M. Tech.

PhD/D. Sc./D. Tech

Others

\section{OCCUPATION}

\section{ORGANIZATION}

6. LOCATION (local Government and State)

7. COMPUTER LITERACY LEVEL (Pls. Tick $(\sqrt{ })$ as appropriate)

\begin{tabular}{l}
\hline Excellent \\
\hline Very Good \\
\hline Good \\
\hline Average \\
\hline Poor \\
\hline
\end{tabular}


8. UNDERSTANDING OF THE INTERNET (Pls. Tick $(\sqrt{ })$ as appropriate)

\begin{tabular}{l}
\hline Excellent \\
\hline Very Good \\
\hline Good \\
\hline Average \\
\hline Poor \\
\hline
\end{tabular}

9. UNDERSTANDING OF FINANCIAL/COMPUTER CRIME (Pls. Tick $(\sqrt{ })$ as appropriate)

\begin{tabular}{l}
\hline Excellent \\
\hline Very Good \\
\hline Good \\
\hline Average \\
\hline Poor \\
\hline
\end{tabular}

10. HAVE YOU BEEN A VICTIM OF COMPUTER CRIME (Please Tick $(\sqrt{ })$ as appropriate)

\begin{tabular}{l}
\hline Yes \\
\hline No \\
\hline
\end{tabular}

IF YES:

a. TICK $(\sqrt{ })$ AS APPROPRIATE, THE RANGE OF OCCURRENCES

\begin{tabular}{l}
\hline $1-5$ \\
\hline $6-10$ \\
\hline $11-15$ \\
\hline $16-20$ \\
\hline Above 20 \\
\hline
\end{tabular}

\section{b. TICK ( $(\sqrt{)}$ AS MANY AS POSSIBLE MODE OF OCCURRENCES}

\begin{tabular}{l}
\hline Advance fee fraud ("Yahoo Yahoo") \\
\hline Forgery (Fake Office Documents, Certificates, etc.) \\
\hline ATM (Money Theft Through ATM) \\
\hline Piracy (Pirated Software, Video/Audio CDs, etc.). \\
\hline Phreaking (Making Fraudulent free calls) \\
\hline Spamming (Unsolicited emails) \\
\hline Embezzlement (Executive Theft, Salami Shaving. etc.). \\
\hline Computer Virus and/or Denial of Service \\
\hline Pornography/Financial Grooming \\
\hline Others(Specify): \\
\hline
\end{tabular}

13. Financial Crime Gender Incidence

\begin{tabular}{lllll}
\hline Index & Very High & High & Medium & Low \\
\hline Male & & & & \\
\hline Female & & & & \\
\hline
\end{tabular}




\section{Financial Criminals' Age Range}

\begin{tabular}{lllll}
\hline Index $\quad$ Very High & High & Medium & Low \\
\hline $2-11$ & & & & \\
\hline $12-17$ & & & \\
\hline $18-25$ & & & & \\
\hline $26-45$ & & & \\
\hline Above 45 & & & \\
\hline
\end{tabular}

\section{Section B: Assessment of Financial Crime Counter Measures}

\begin{tabular}{|c|c|c|c|c|c|}
\hline SNo. & Index & Excellent & Very Good Good & Average & Poor \\
\hline 1 & Political will & & & & \\
\hline 2 & Industry Contribution & & & & \\
\hline 3 & Funding of Research on Financial Security & & & & \\
\hline 4 & Societal Campaign & & & & \\
\hline 5 & Employment generation & & & & \\
\hline 6 & Economic Stability and Political stability & & & & \\
\hline 7 & Moral upbringing & & & & \\
\hline 8 & Social equality and Fairness & & & & \\
\hline 9 & Pro-Active (Preventive) Measures & & & & \\
\hline 10 & Re-Active (Curative) Measures & & & & \\
\hline 11 & National orientation & & & & \\
\hline 12 & Religious campaign & & & & \\
\hline 13 & Public/Private Agency Collaboration & & & & \\
\hline 14 & Ruggedness of Financial System's Design & & & & \\
\hline 15 & Physical Security at Financial Institution & & & & \\
\hline 16 & $\begin{array}{l}\text { Implementation of Appropriate Legislative } \\
\text { Framework }\end{array}$ & & & & \\
\hline 17 & $\begin{array}{l}\text { Implementation of Effective Investigative } \\
\text { Framework }\end{array}$ & & & & \\
\hline 18 & Reward for Integrity, excellence and honesty & & & & \\
\hline 19 & $\begin{array}{l}\text { Scalability of Hardware at Financial } \\
\text { Installations }\end{array}$ & & & & \\
\hline 20 & $\begin{array}{l}\text { Effectiveness of Financial Criminal Tracking } \\
\text { Software }\end{array}$ & & & & \\
\hline 21 & $\begin{array}{l}\text { Availability of Forensic Experts (Forensic } \\
\text { Accounting) }\end{array}$ & & & & \\
\hline 22 & $\begin{array}{l}\text { Execution of Regular Auditing in Financial } \\
\text { Institutions }\end{array}$ & & & & \\
\hline 23 & Regular Staff Training on Financial Crime & & & & \\
\hline 24 & $\begin{array}{l}\text { Internal Control System, Policies, Laws and } \\
\text { Operations }\end{array}$ & & & & \\
\hline 25 & Adherence to Due Process & & & & \\
\hline 26 & Data Analytics and Visualization & & & & \\
\hline 27 & $\begin{array}{l}\text { Effective Predictive Modelling and Strong } \\
\text { warning System }\end{array}$ & & & & \\
\hline 28 & Effective Financial Data Management & & & & \\
\hline
\end{tabular}




\section{Appendix 2: Correlation Matrix}

\begin{tabular}{|c|c|c|c|c|c|c|c|c|c|c|c|c|c|c|c|c|c|c|c|c|c|c|c|c|c|c|c|c|}
\hline 78 & PW & IC & FR & SC & EG & EPM & MU & SEF & PAM & RAM & No & RC & PPC & RFS & PSF & IAL & IIF & RIE & SHF & ETS & AfE & ERA & RST & ICS & $A D P$ & DAV & EPM & EFD \\
\hline$P W$ & 1.00 & .670 & 597 & .476 & 379 & .399 & .374 & .400 & 447 & .405 & .439 & .402 & .384 & .367 & .375 & $A 12$ & .432 & 429 & .403 & 377 & .403 & 362 & .386 & .349 & .392 & .401 & 391 & .399 \\
\hline IC & .670 & 1.00 & .674 & .521 & .469 & .483 & .444 & .469 & .481 & .418 & .436 & .375 & .380 & .414 & .379 & .467 & .474 & .458 & .446 & .421 & .434 & .403 & .413 & .384 & .434 & .426 & .424 & .407 \\
\hline FR & .997 & .674 & 1.00 & .618 & .574 & .595 & .910 & .509 & .576 & .486 & .490 & .436 & .472 & .481 & .452 & .453 & .476 & 548 & .454 & .483 & .497 & .433 & .478 & .432 & .461 & .483 & .489 & .463 \\
\hline$S C$ & .476 & .521 & .618 & 1.00 & .664 & .598 & .905 & .542 & 478 & .425 & .460 & .395 & .426 & .48 & .404 & .437 & .446 & 508 & .444 & 489 & .509 & 388 & .482 & .421 & .441 & .470 & .459 & .483 \\
\hline EG & .379 & .469 & 574 & .664 & 1.00 & .716 & .607 & .574 & .573 & .468 & .466 & .364 & .443 & .472 & .413 & 507 & .495 & 595 & .454 & 521 & .528 & .444 & .521 & 479. & .466 & .478 & .497 & .489 \\
\hline EPS & .399 & .483 & 595 & .998 & .716 & 1.00 & .693 & .579 & 969 & .431 & .478 & .386 & .405 & .42 & .390 & .471 & .910 & 533 & .439 & .481 & .521 & .422 & .513 & .460 & .468 & .498 & .452 & .489 \\
\hline MU & .374 & .444 & 510 & .905 & .607 & .693 & 1.00 & .622 & 990 & .496 & .917 & .414 & .446 & .432 & .443 & .493 & .914 & 538 & .473 & .483 & .454 & .434 & .496 & .437 & .463 & .496 & .480 & .907 \\
\hline SEF & .400 & .469 & .509 & .942 & 574 & .579 & .622 & 1.00 & .629 & .549 & .918 & .403 & .462 & .459 & .373 & .444 & .489 & 519 & .479 & 505 & .519 & .449 & .468 & .471 & .498 & .497 & 503 & .497 \\
\hline PAM & .447 & .431 & 576 & .478 & .573 & .565 & .990 & .629 & 1.00 & .681 & .949 & .461 & .489 & .499 & .411 & .455 & .512 & 541 & .477 & 509 & .515 & .474 & .457 & .471 & .504 & .534 & .485 & .494 \\
\hline RAM & .409 & .418 & .486 & .425 & .468 & .431 & .456 & .949 & .681 & 1.00 & .960 & .482 & .448 & .451 & .362 & 396 & .446 & .447 & .441 & .403 & .431 & .410 & .397 & .417 & .446 & .495 & .475 & .436 \\
\hline NO & .439 & .436 & 490 & .450 & 466 & .478 & .917 & .518 & 549 & .960 & 1.00 & .547 & .559 & .488 & .912 & .473 & .448 & .411 & .449 & .406 & .468 & .470 & .514 & .457 & .443 & .481 & .464 & .436 \\
\hline RC & .402 & .375 & .436 & .395 & 364 & .386 & .414 & .403 & .461 & .482 & .947 & 1.00 & .980 & .474 & .459 & 390 & .342 & .432 & .410 & 355 & .319 & 349 & .399 & .344 & .363 & .430 & .416 & .392 \\
\hline PPC & .384 & .380 & .472 & .426 & .443 & .405 & .446 & .462 & .489 & .448 & & .580 & 100 & .609 & .512 & .452 & .391 & .436 & .458 & .423 & .446 & .428 & .490 & .459. & .469 & .474 & .472 & .510 \\
\hline RFS & .367 & .414 & 481 & .448 & .472 & .442 & .432 & .459 & .449 & .451 & .488 & .474 & .609 & 1.00 & .965 & 508 & .446 & 481 & .407 & .444 & .440 & 422 & .463 & .468 & .472 & .431 & .469 & .489 \\
\hline PSF & 379 & .379 & .452 & .404 & 413 & .390 & .443 & .373 & .411 & .362 & .512 & .459 & .512 & .565 & 1.00 & 572 & .525 & .442 & .493 & .441 & .438 & .431 & .444 & .407 & .446 & .461 & .447 & .436 \\
\hline IAL & .412 & .457 & .453 & .437 & .907 & .471 & .453 & .444 & .455 & .396 & .473 & .390 & .452 & .908 & .572 & 1.00 & .617 & 593 & .498 & 500 & .489 & .449 & .469 & .441 & .513 & .490 & .483 & .478 \\
\hline$\| F$ & .432 & .474 & .476 & .446 & 499 & .510 & .914 & .489 & 512 & .446 & .448 & .342 & .391 & .46 & .525 & .617 & 1.00 & .619 & .932 & .930 & .518 & 488 & .478 & .469 & .493 & .457 & .479 & .452 \\
\hline RIE & .429 & .458 & 548 & .908 & 559 & .533 & .538 & .519 & 541 & .447 & .411 & .432 & .436 & .481 & .442 & 553 & .615 & 1.00 & .624 & .625 & .572 & 515 & .515 & .522 & .595 & .569 & 524 & .493 \\
\hline SHF & .403 & .446 & .494 & .444 & .454 & .439 & .473 & .479 & .477 & .441 & .449 & .410 & .458 & .407 & .493 & .498 & .932 & .624 & 1.00 & .628 & .981 & 526 & .510 & .497 & .523 & .533 & .498 & .501 \\
\hline ETS & .377 & .421 & .483 & .489 & .521 & .481 & .483 & .509 & .909 & .403 & .406 & .359 & .423 & .444 & .441 & 500 & .930 & .623 & .628 & 1.00 & .692 & 561 & .533 & .900 & .536 & .961 & 522 & .500 \\
\hline AFE & .403 & .434 & 497 & .909 & 528 & .521 & .454 & .519 & 515 & .431 & .468 & .319 & .446 & .40 & .438 & .489 & .918 & 572 & .981 & .692 & 1.00 & .669 & .601 & & .548 & .964 & .489 & .519 \\
\hline ERA & .362 & .403 & .433 & .388 & .444 & .422 & .434 & .449 & .474 & .410 & .470 & .349 & .428 & .422 & .431 & .449 & .488 & 515 & .526 & 561 & .665 & 100 & .690 & .580 & .503 & .523 & .472 & .463 \\
\hline RST & .386 & .413 & .478 & .432 & 521 & .513 & .496 & .468 & .457 & .397 & .914 & .399 & .450 & .463 & .444 & .469 & .478 & 513 & .910 & 533 & .601 & .690 & 1.00 & .662 & .604 & .598 & 548 & .478 \\
\hline ICS & .349 & .384 & .432 & .421 & .479 & .460 & .437 & .471 & .471 & .417 & .457 & .344 & .459 & .468 & .407 & .441 & .465 & 522 & .497 & 500 & .599 & 980 & .662 & 1.00 & .691 & .869 & 537 & .520 \\
\hline ADP & .392 & .434 & 461 & .441 & .466 & .468 & .463 & .498 & .904 & .446 & .443 & .363 & .469 & .472 & .446 & 513 & .493 & 559 & .523 & 536 & .548 & 503 & .604 & .651 & 1.00 & .672 & 585 & .528 \\
\hline DAV & .401 & .426 & .483 & .470 & .478 & .498 & .496 & .497 & .534 & .495 & .481 & .430 & .474 & .481 & .461 & .490 & .457 & 569 & .533 & 561 & .564 & 523 & .598 & .989 & .672 & 1.00 & .687 & .631 \\
\hline EPM & .391 & .424 & .485 & .455 & 497 & .452 & .480 & .503 & .485 & .475 & .464 & .416 & .472 & .469 & .447 & .483 & .479 & 524 & .458 & 522 & .489 & .472 & .548 & .537 & .585 & .687 & 1.00 & .692 \\
\hline EFD & .359 & .407 & 463 & .483 & 489 & .489 & .907 & .497 & .494 & .436 & .436 & .392 & .510 & .489 & .436 & .478 & .452 & .493 & .901 & 500 & .519 & 463 & .478 & .520 & .528 & .631 & .652 & 1.00 \\
\hline
\end{tabular}

